Article

\title{
Business Models for Social Innovation of Municipal Solid Waste Recycling Companies: Comparison of Two Business Cases in Thailand and Taiwan
}

\author{
Xiujuan Chen ${ }^{1}{ }^{(0)}$, Chih-Tsung Tai ${ }^{2}$, Linhai Wu ${ }^{1}$, Fu-Sheng Tsai ${ }^{2,3, *(\mathbb{D})}$ and \\ Kotchaphorn Srimanus ${ }^{2}$ \\ 1 Institute for Food Safety Risk Management, School of Business, Jiangnan University, Wuxi 214122, China; \\ cxj8710@163.com (X.C.); wlh6799@jiangnan.edu.cn (L.W.) \\ 2 Department of Business Administration, Cheng Shiu University, Kaohsiung 83347, Taiwan; \\ drdstai@hotmail.com (C.-T.T.); srimanuskotchaphorn49@gmail.com (K.S.) \\ 3 Loonguard Research Institute, Guangzhou 510000, China \\ * Correspondence: fusheng_tsai@hotmail.com; Tel.: +86-7-731-0606
}

Received: 5 March 2018; Accepted: 26 March 2018; Published: 29 March 2018

\begin{abstract}
The significant increase of municipal solid wastes (e.g., food disposals, biomedical wastes, recyclable materials, etc.) is a very important environmental issue around the world. Waste recycling, reduction, and reuse are not only methods to solve environmental problems, but also directions for social innovation for business to create potential social value. This study investigates the business models of two waste recycling companies in Thailand and Taiwan. First, the basic micro and macro environmental factors were analyzed, including the period of firm's business operations, location of the firm, space for separating and storing recyclable waste and various types of recyclable waste purchasing affecting the firms' performance in these two economies. Second, different recyclable waste materials, volumes and price strategies between the case companies were compared. Third, this study also investigates the impacts of factors regarding resource characteristics, a firm's capabilities and an entrepreneur's abilities to improve a firm's performance all compose a critical business model. The results showed that there were an increasing number of owners of waste recycling businesses developing and adapting to new business models. Detailed comparisons are reported and discussed in the article to shed light on managerial and policy implications.
\end{abstract}

Keywords: recycling; municipal solid wastes; business models; social innovation

\section{Introduction}

Global warming is a problem that affects all of the world's populations in all countries [1,2]. The problems are caused by economic growth, population growth, and shortened natural resources [3]. In such a setting, people care more about the green and efficient use of all resources and products to maintain a sustainable environment. Especially in the industrialized world, if consumers think first of the environment, this will decrease the level of pollution and quantity of garbage [4].

Hence, sustainable solid waste management is a high-priority issue that needs to be addressed. A significant increase of municipal solid wastes is one of the main environmental issues in both developed and developing countries [5]. The quality of the environment is, therefore, a matter of growing concern, and a considerable improvement in recycling and composting performance has been achieved. In general, recyclable waste is defined as waste that can be processed into raw materials. Examples include foods, paper, metal, glass, and plastic. We have a strong desire to focus on the difference in the recycling industry between companies of Thailand and Taiwan in terms of business models. It can be measured in nominal terms, which are adjusted for inflation. The results can be 
used as a guide for those interested in the recycling industry business including understanding and adapting for support in business [6].

By investigating business models, social innovation as a very important issue can be discussed. Waste ventures use start-up capital from foundations, social-impact investors, and enhance them to create a business operational model and to promote the industrial techniques and skills when they want to compete with other competitors [7]. As Reference [8] have stated, "... recent years have seen tremendous growth in the value and visibility of social innovation assets from our environment," companies and pubic units may invest and create the recycling value for the micro and macro stakeholders [9].

\section{Materials and Methods}

According to the discussion of the research background, we try to describe the recycling industry in the case of Thailand and Taiwan. Then, we want to compare various factors and research on the quality of natural resources and organizational ability by duration. Finally, we shall present a view of the various factors and research needed when deciding to create a business that is about the environment industry. Our research objectives are: (1) To understand the business models of waste recycling companies in Thailand and Taiwan, from a social innovation perspective; (2) To understand the internal and external factors that influence the business models, with sustainability implications; (3) To add practical suggestions and help raise awareness to everyone in society for waste processing organizations' use and sense of sustainability.

\subsection{Methodology}

In many developing countries, local waste collectors or private companies actively recycle waste in an efficient manner. For this research, a qualitative research methodology is adopted. This way, we can study the stories and experiences of the owners of recycling businesses since they know a lot in this area. Therefore, we need to analyze what the owner learned from their recycling business and their experiences. Then we have to analyze the data from the experience of the owners of the recycling business.

\subsection{Case Companies}

This research has two sources of key information-an owner of a recycling business in Taiwan and another one from Thailand. The case companies are: (1) Wongpanit Co., Ltd. (Kheha Romklao franchises store in Bangkok, Thailand); and (2) Da Fon Environmental Technology Co., Ltd. (Da Li franchises store in Taichung, Taiwan).

Both the owners of the recycling business have been doing the business for at least twenty years or more and have many experiences with managing the business.

\subsection{Data Collection and Analysis Procedures}

(1) First, we collect data from the literature review, book, article, information, other theses and other research about the recycling industry in Thai, Chinese and English, including from websites about recycling and solid waste management, the basic knowledge about doing the recycling business, ideas about the enterprise, and ideas about management.

(2) Second, the researchers interviewed the owner of the recycling businesses in Thailand and Taiwan, on site.

(3) Third, the result is translated and analyzed when the interview is finished.

Table 1 shows the interview information from Thailand and Taiwan. 
Table 1. Interview Information for Thailand and Taiwan.

\begin{tabular}{ccc}
\hline Items & Thailand & Taiwan \\
\hline Company & $\begin{array}{c}\text { Wongpanit Co., Ltd. (Kheha } \\
\text { Romklao Franchises Store). }\end{array}$ & Da Fon Environmental Technology Co., Ltd. \\
\hline $\begin{array}{c}\text { The } \\
\text { Respondent/Position }\end{array}$ & $\begin{array}{c}\text { Mrs. Sirikorn Srimanus, } \\
\text { General Manager. }\end{array}$ & $\begin{array}{c}\text { Mr. Lee Hong Yi, Assistant Manager, } \\
\text { Operations Management Office, North } \\
\text { District Operations Center. }\end{array}$ \\
\hline Time & January 2016 & May 2016 \\
\hline Place & Bangkok, Thailand & Taichung, Taiwan \\
\hline
\end{tabular}

\section{Results and Discussions}

\subsection{Industrial Settings}

\subsubsection{Recycling Industry in Thailand}

According to Interior Ministry statistics, garbage nationwide in 2016 amounted to 27 million tons where it had increased by up to about $0.7 \%$ from the previous year. In addition, the data of the Department of Environment Administration in Bangkok shows that the garbage problem is one of the major factors for environmental problems such as air pollution which causes problems by burning garbage and water pollution caused by residue garbage flowing into the river. Residue garbage becomes an area for the breeding of rats and flies. It is the source of disease vectors and affects the health of the people. Garbage also causes annoyance due to its putrid smell and the uncleanliness from the inefficient garbage collection [10-12].

The main reason for the rapid increase in the amount of garbage in Thailand is its economic and social growth. It causes the garbage removal process to be complex and more difficult [13]. Therefore, the amount of garbage is increasing. In 2014, the amount of garbage throughout the Thailand is about 14.3 million tons, or 39,221 tons per day. It is decreasing by 8291 tons per day. While the amount of garbage in the municipality occurred adds up to about 18,295 tons per day. Reduction of garbage in Bangkok in 2014 is the result of policies to reduce garbage by $10 \%$. In other areas, the amount of garbage continues to increase. It might be due to the increase in population growth, community growth, stimulation of the economy, promotion and tourism development. Especially in provincial areas, the amount of garbage has increased continuously in all regions of Thailand [14].

\subsubsection{Recycling Industry in Taiwan}

From the 1950s, Taiwan became industrialized more rapidly, leading to higher garbage and waste output from factories and families; then environmental protection became a concern. To combat the pollution and waste problems, recycling became a great issue of private efforts and government regulations. The people of Taiwan have progressed far in recycling and minimizing waste. They are responsible for bringing their own trash to collection places in the communities. Until 2015, the overall recycling rate has become $57 \%$ - even higher than those of many advanced nations, including France, Japan, the United Kingdom and the United States [15,16].

In Taiwan, garbage collection trucks are known to play music to alert people to their presence at collection places five days a week. Consumers are encouraged to purchase items bearing the Green Mark logo, which denotes recyclability or a lower environmental impact compared with similar products available. 
Meanwhile, the promotion of food-waste recycling over the past eight years has been highly successful, with the amount recycled per day rising from 80 tons in 2001 to 2710 tons in 2014 . About $75 \%$ of food waste is steam-treated for use as pig feed, and $25 \%$ enters composting systems.

Figure A1 shows the statistics of waste generated in Taiwan from 2002 to 2016 . We can find that the total amount of waste generated decreased; recycling and reuse amount increased, and the amount of waste generated per capita per day became less than $0.9 \mathrm{~kg}$ in 2011.

According to Table A1, showing the overall results of the recycling industry in Thailand in 2016, we found the recycling business in Thailand has been buying the 6 main types of recyclable waste-namely steel, paper, glass, plastic, metal and electronics. The highest price of material is metal which is about NTD 43.7, but it has the lowest average volume. The average volume of metal per year is about 30,000 tons, because some types of metal include copper, brass and aluminum. This means that this type of metal has the highest price. The highest average volume per year is paper and plastic, having an average price of NTD 3.45 and NTD 4.04, respectively. These recycling businesses focus on paper and plastic because there were other activities related to recycling paper and plastic such as the destruction of classified documents and transforming plastic processing that can make the business buy many more materials.

The recycling business in Taiwan has been buying the 5 main types of recyclable wastes namely steel, paper, plastic, metal and electronics. However, they do not buy glass (while those in Thailand do). The highest and lowest prices of material is metal, which is similar with the recycling industry in Thailand. We can say that Taiwan Government has more scientific regulations and policies for recyclable waste material and have created a good recycling chain in the industry. Taiwan's economic structure is similar to Thailand but the development level of industry is more advanced. Thailand, however, practically imported equipment and established suitable regulations.

\section{Business Model Comparison}

We collect and compare factors in the recycling industry between Taiwan and Thailand, as shown in Table A2. Furthermore, after we finished with the interviews, we summarized the comparison between two cases from Thailand and Taiwan in Table 2.

The material with the highest price is metal-which is around NTD 43.7-but metal has the lowest average volume. Metal has an average volume of 30,000 tons per year. This type of metal includes copper, brass and aluminum. This type of metal has the highest price. The highest average volume per year is paper and plastic. They have an average price of NTD 3.45 and NTD 4.04, respectively. Because these recycling businesses focus on paper and plastic, there were other activities related to recycling paper and plastic such as demolishing of classified documents and transforming plastic processing that can make the business buy much more materials.

For Taiwan's situation, the interviewee told us that the prices of recyclable materials were getting lower in recent years. The highest price of material is metal which is similar in the recycling industry in Thailand. The lowest price of material is paper, which is also the same as in Thailand.

In addition, we found that in the business order section, the Thailand case does not only recycle material, but they also export to overseas countries like Mainland China because they have enough recycling material of their own. On the contrary, the recycling material can only be recycled in Taiwan because it is relatively smaller. As to the intentions of the people who collect recyclable wastes in Thailand and Taiwan, the main reason most of the people from Thailand collect recyclable wastes is to earn money. One of the reasons was because price of material in Thailand is higher and some people who are familiar with collecting recyclable wastes treat it like a job. 
Table 2. The Comparison between Two Cases.

\begin{tabular}{|c|c|c|}
\hline Questions & Thailand Interviewer & Taiwan Interviewer \\
\hline How many employees does your company have? & $\begin{array}{l}\text { We have around } 60 \text { people and above in our store. A } \\
\text { franchise is about } 6 \text { to } 10 \text { people. }\end{array}$ & $\begin{array}{l}\text { Headquarter has about } 60 \text { people (franchise is } \\
\text { excluded), a franchise is about } 5 \text { to } 6 \text { people, a manager, } \\
\text { an accountant, two packers and two drivers. }\end{array}$ \\
\hline Does your company have any franchises? & There are around 700 franchisees branches in Thailand. & There are 42 franchises currently in Taiwan. \\
\hline $\begin{array}{l}\text { What is the specific consideration when setting up } \\
\text { the factory? }\end{array}$ & $\begin{array}{l}\text { It's a great opportunities to develop the recycling } \\
\text { industry in Thailand, especially to expand the business } \\
\text { to the nearly countries; such as China, Vietnam and } \\
\text { other developing countries. }\end{array}$ & $\begin{array}{l}\text { There are no regulations from the government } \\
\text { for the industrial land; it is generally commercial } \\
\text { land and residential land. But we have a clean } \\
\text { factory with densely population and next to the } \\
\text { highway for transportation. }\end{array}$ \\
\hline What are the prices of the materials? & $\begin{array}{l}\text { The price have been set by recycling association or the } \\
\text { large processing plant (paper, glass, plastic seed, and } \\
\text { steel/iron wire processing factories) and they will } \\
\text { update price in day by day at } 8 \mathrm{o}^{\prime} \text { clock in the morning. }\end{array}$ & $\begin{array}{l}\text { The price changes every Monday. It depends on the } \\
\text { market supply and demand. }\end{array}$ \\
\hline $\begin{array}{l}\text { About you store, what kind of materials } \\
\text { do you purchase? }\end{array}$ & $\begin{array}{l}\text { Almost have all kind of materials; there are six main } \\
\text { types of materials such as Iron/Steel, Metal, Plastic, } \\
\text { Paper, Glass and Electrical appliances. }\end{array}$ & $\begin{array}{l}\text { Normally metal, paper and plastics. We are } \\
\text { expanding our business currently and we are } \\
\text { doing the PLA experiment. }\end{array}$ \\
\hline What is the leading material to sell at the store? & $\begin{array}{l}\text { The customers who bring the materials to sell for us is } \\
\text { divided into two large groups, follow by: } \\
\text { 1. Buy the materials at the front of recycling store, this is } \\
\text { the customers was bringing the materials by } \\
\text { themselves. The Customer was from the household; } \\
\text { nearly village, wheelbarrow, tricycle and the collecting } \\
\text { recyclable wastes' truck. } \\
\text { 2. Buy the materials at the source of materials, this is } \\
\text { the owner of the recycling store will going to the source } \\
\text { of materials place and take it to the store for calculate } \\
\text { such as a factory, hospital, school, office. }\end{array}$ & $\begin{array}{l}\text { Our customers are old people, family, small shops, } \\
\text { restaurants, supermarkets, companies and factories. }\end{array}$ \\
\hline $\begin{array}{l}\text { After you purchase the materials, what do you do } \\
\text { with the materials? }\end{array}$ & $\begin{array}{l}\text { Buy the material at the front of the recycling store, there } \\
\text { has separated the garbage by the type of the garbage. } \\
\text { After that the garbage will be keep in the warehouse, } \\
\text { then the garbage will be hard pressed to square for } \\
\text { reduce production costs and easies to transport. }\end{array}$ & $\begin{array}{l}\text { We will separate them into different categories, such as } \\
\text { paper and plastics and also old clothes, but we do not } \\
\text { recycle glass. }\end{array}$ \\
\hline
\end{tabular}


Table 2. Cont

\begin{tabular}{c} 
Questions \\
\hline In the past, are you affected by the economi
\end{tabular}

change? If you are affected, what do you do?

In business, did you encounter any problems? And how do you solve the problem?

How do you adapt with your employees? How do you adapt with fluctuating costs and customers?
If the economy is in a recession, however, in terms of

waste recycling. Asked whether affects you but it is not the same as other businesses. The cost of doing

business is low, so it is a business with very little impact on waste.

But I know that if there is such a problem that China was selling steel. Much cheaper than Thailand Steel oversupply in Thailand because buyers turn to buy steel from China. Make regular scrap must be returned to melt and back to the new sales are not enough sales, not price it lower. This is the result of one of the world's economy.

This is the advantage of doing business recycling one. The shop waste is pricing itself. Because when we are able to sell as much. It's depressing, but it was sold at a price we think. It will be profitable for us. We will buy at a price as low as we buy steel at a price that is a lot. Domestic steel purchases were only four baht, but we have to sell it to smelters is about 6-7 baht so it will still be profitable, but clients or people who do not recycle it and sell to us it will be a very low price. Most will have an impact on those who sell their products to us over.

Most of the workers of this recycling store. We use foreign labor. But it's not a problem. Because, we pay by the due of Thailand labor law. But the problem is that Thai's labor problem because Thailand is a non-popular work in this type of business. Thailand is considered to be a business that is not heavy, clean and not look bad, this business making it difficult for Thai's workers. Maybe it's because some jobs require workers Thailand. We are not having the problem with the customers, because customers have to rely on the reputation of the company.
We almost collapsed in the global economic crisis in 2003 , because the scrap price drop dramatically, the spread with selling is just enough to cover our loss.

We are just doing our up line business, because the down line has lots of problems to solve. We will not meddle unless they really need us.

The human resources management department will solve this. 
Table 2. Cont

\begin{tabular}{|c|c|c|}
\hline Questions & Thailand Interviewer & Taiwan Interviewer \\
\hline $\begin{array}{l}\text { What are the key factors that make a business } \\
\text { successful and survive? }\end{array}$ & $\begin{array}{l}\text { The intention is to do business successfully. We think } \\
\text { we have achieved nearly } 100 \% \text { of the intention. We do } \\
\text { not mind in recycling business. And this business can } \\
\text { make a profit out faster. It is more and more waste, and } \\
\text { if we do not take helps to recycle. It will be the burden } \\
\text { to the central government to the need to recycle more, } \\
\text { so our business has helped in many ways. }\end{array}$ & $\begin{array}{l}\text { Now we have to do something no one has done, we do } \\
\text { not know what the problem is until we make it. Since } \\
\text { we are not the design of information industry, how to } \\
\text { be a large platform, how to integrate down line with the } \\
\text { platform. We hope to find the headstream without } \\
\text { intermediary, this could cut down cost. All this is still in } \\
\text { the state of fumble. }\end{array}$ \\
\hline
\end{tabular}

thelp in many ways.

We expect our business will be growing forward. But

now we think it is okay. But in the future we're going to move to the other business; we have to change the perspective of the business Recyclable Waste from the storefront. As a new business, such as sabotage

What changes do you expect to see in the business?

Regarding the stories, we have talked about, do you want to tell me more or do you have any other opinions you want to add? products, sabotage the secret documents, destroying or damaging the products, its copyright has expired. This is a new business; we think it will grow in the future. may be popular in the future. We already do some of business that was done. It is quite complicated in process. Now we have already taken in some part and the future will be full part.

In our view, Wongpanit Recycling Business was a very good business that wants everyone to help the environmental together. The waste can be change into money. To protect the environment, I wholeheartedly we are quite happy with this we want to grow with the business. The other business segments, we did not think too much. This may increase the factory production increased over
We have been implementing entity continuously and we hope to have an integration model in Taiwan, like the internet in China. Besides, we develop a useful App for providing the customers and supplies to buy and sell the recyclable materials with the platform. We also provide an intelligence device on the poor and old people who collect the recyclable materials, when they come across the streets, people can check the platform and provide goods for them.

The steel factory and paper factory is gather in the central and the southern, while the price northern part is lower but the transportation cost is higher. I can't give you too much information because it is very sensitive; you can go to the factory and find out by yourself. 
Moreover, Thailand companies have on average 60 workers, which is 10 times more than Taiwan. The space is also bigger than Taiwan. With regards to the difference in the transportation and the transaction processes between two case companies, the researcher found that the recycling stores in Taiwan have to depend on the head office. The head office will pay the money to the recycling store, but the recycling store has to transport the recycling material to the large processing plants by themselves, which is different from the Thai companies.

More specifically, this study found that the recycling industries in Taiwan and Thailand have some different points in macro and micro factors as follows.

\subsection{Macro Factors}

1. Population: From the result, Thailand is geographically bigger than Taiwan, and the population is also larger than in Taiwan.

2. Laws: Even though Thailand and Taiwan almost have the same regulations, Thailand's regulation is still weak. This is because Thailand's population was larger than Taiwan's. The government has not enough power to control and give the information about the pollution problem in the environment to their people.

3. The cooperation of the government: we found that Thailand has $80 \%$ of the private sector who manage the garbage such as general garbage trucks, separate garbage stations and so forth. Some of the waste disposal was also managed by the private sector. This was different from Taiwan, where just $20 \%$ of the private sector is in charge of the waste recycling business

4. Competition: In Thailand there is high competition, for which control for rich natural resources that can be recycled is critical. Moreover, Thailand also exports the recyclable materials overseas. That is the main reason for investing and being interested in the recycling business. In Taiwan, there are only 8 branches of franchise stores and all of them have to depend on the head office. Thus, the competition factor was low.

5. Business order: Thailand has business orders in its own country and overseas. This is because Thailand has lots of natural resources that can be recycled. On the other hand, Taiwan just has business orders locally-because of the small geographic coverage, there is not much to export overseas.

6. The intention of the people who collect recyclable wastes: Most of the people in Thailand have the intention to collect recyclable wastes for earning money, because the price of material in Thailand is higher and some people are used to collecting recyclable wastes as their job. Most of the people in Taiwan have the intention to collect recyclable wastes to protect the environment. One of the reasons is that throwing the recyclable wastes in the recyclable waste bin is part of the Taiwanese lifestyle.

7. How frequently do the garbage trucks collect the garbage: In Thailand, the garbage trucks collect the garbage twice a week for general trucks, and there is no garbage truck that collects recyclable materials. In Taiwan, the garbage truck collects the garbage every day, except on Sundays. Moreover, there are many recycling garbage trucks that collect the garbage together with the general garbage truck twice a week. Relatively, Taiwan has almost no public garbage bin. Because of this incredibly annoying phenomenon, all the trash that one accumulates during the day is carried on and dumped in a bin at home. Then a big yellow garbage truck blasting musical tones comes around, followed by a smaller recycling truck, and everyone dumps their garbage and recyclables. The garbage truck rarely has to stop for more than a few seconds. Everyone is ready and the process has been truly optimized.

8. The effects of economic change: In Thailand, the recycling store was affected by the economic changes from the Thailand Flood in 2011, making the store unable to sell the materials. In Taiwan, the recycling store was affected by the World financial crisis in 2007, but only gently. Because their business order was head office, the head office will support the price of the materials and maintain it. 
9. The variety of garbage trucks: In Thailand, they only have general trucks to collect the garbage in their country. In Taiwan, general trucks and professional recycle garbage trucks collects the garbage in the whole country.

10. The method of solid waste disposal: In Thailand, landfill and composing is the primary method of solid waste disposal. Incineration is the auxiliary method. Because Thailand has a large country plan, most people carelessly use landfill and composting methods, which is cheaper than the incineration method. In Taiwan, landfills and composting are the primary methods and incineration is the auxiliary method.

11. The classification of the wastes disposal in two countries: the two countries have the same 4 types of classification of the wastes.

\subsection{Micro Factors}

1. Age of the owner: In Thailand, the age of the owner was 25 years and above.

2. Office hours: In Thailand, the recycling store is open every day, but in Taiwan, recycling stores are open from Monday to Saturday and closed on Sunday.

3. Location: The location of the recycling store in Thailand was outside the city and is 1200 square meter in size. It is 6 times bigger than Taiwan's. The location of the recycling store in Taiwan was in the city, the owner said this was so that the customers can easily sell the recyclable materials. But the plan size was 150-200 square meter. This is because company regulation wants to control the volume of material and transportation problem of the material.

4. Employees: The employees of the recycling store in Taiwan consist of 6 workers, namely 1 owner, 1 officer, 2 drivers, and 2 separate waste workers. Because there is no larger plan, 6 workers were enough. The recycling store in Thailand has 60 workers, most of them are separate waste workers. They are not Thai. They are from Myanmar, Laos and Cambodia. This is because Thai people do not like to work with garbage; they think it is a dirty job.

5. Price of materials: In the two economies, the price of the materials is almost the same. But Thailand has higher prices than Taiwan. One of the reasons is that Thailand has business from overseas.

6. Management of the recyclable wastes: In Thailand, the management of recyclable waste was separate to the type of item. For example, they have to cut the plastics bottles into smaller pieces to make a higher price. But in Taiwan they just only separate into the plastic type and did not separate the color of plastic like in Thailand.

7. Franchise fee: To start the business, both Thailand and Taiwan owners have to pay the franchise fee. In Thailand, they pay about USD 6600 dollars. In Taiwan, they pay about USD 9800 dollars.

8. The margin: In Thailand, the franchisees do not need to pay the margin cost. But in Taiwan, the franchisees have to pay the margin cost of about USD 16,600 for every five years. This is because the head office will help the franchisees contact the material prices to the factory.

9. Construction plan and start-up costs: In Thailand, the recycling store used about USD 50,000 for construction plan and start-up cost. In Taiwan, the recycling store used about USD 8300-9800 dollars for construction plan and start-up cost.

10. Revolving fund: In Thailand, the recycling store uses about USD 6700 dollars for a revolving fund. In Taiwan, the recycling store uses about NTD 1,500,000 for revolving fund.

11. Type of materials: In Thailand, the recycling store was buying all types of the recyclable waste except old clothes and wood chips. In Taiwan, the recycling store was buying all type of the recyclable wastes including old clothes, except glass.

12. The difference in transportation and transaction processes: In Thailand, the recycling store has to transport the recycle materials and pay the transaction process. In Taiwan, the recycling store depends on the head office. For example, in the transportation process, the franchisees will go to deliver the recyclable wastes to the large processing plant for transform the product to recycle 
again. Then the large processing plant will pay the money to head office, and then the head office will pay the money to the franchisees. Therefore, the transportation process will depend on head office.

13. For social innovation potential, both companies have developed a good solid waste management and experiences. The companies can provide a privacy effort to satisfy the stakeholders; such as employees, the stockholders, supplies, customers, communities and government.

\section{Conclusions}

Taiwan has well-managed waste and everyone has been concerned about environmental pollution. Both public and private sectors have devoted more attention to solving the waste problem in socially beneficial and innovative ways. Yet in Thailand, there is a considerable amount of recyclable waste dumped into landfills. So, Thailand may need to add some socially innovative waste recycling programs. Overall, the increasing amount of solid waste is a big problem in developing countries. Therefore, the aim of the study is to realize the comparison of the recycling industry and companies in two economies in Asia, especially in the similar economic and social situations of Thailand and Taiwan. This study is a start for future research to dig deeper into the recycling industry.

Due to population differences, as shown in the comparative example here (Thailand and Taiwan), different economies may need to plan and design differently their institutional recycling systems so that they can incorporate different degrees of diversity and scales to meet the needs for recycling. Second, some economies are more suitable for government of the recycling system by the public sector and others for private organizations. This difference in governance mode for institutional recycling systems can also affect the degree of inter-recycler competitions. Third, different reward systems should be designed to stimulate different intentions of the recycling business owners that adopt intentionally different business models. Fourth, technically, the rules of recycling businesses (e.g., location, pricing strategy, frequency of collection, hardware, etc.) were logically set and regulated by governmental units. However, to maximize potential value, rules and regulations should be set after sufficient communication and co-creation with all stakeholders. Fifth, some economies have a lower average age of recycling business entrepreneurs. Ecological entrepreneurship education is significant in affecting the prosperity and motivation of newer generations to take part in such ecological friendly economic businesses.

For future research, guidance and suggestions follow: By using a case study method, this study is exploratory and descriptive in nature. Future studies are encouraged to extract significant elements from our general but wide-covering exploration for potential research and policy issues, and to design and examine those issues with larger-scaled, statistical surveys. These surveys, due to the wide-covering range of the issues explored here, may include those specific to recycling business owners, customers, policy makers, and so forth.

\section{Research Limitations}

1. In Taiwan, there are only a few recyclable garbage stores. The researcher has the capability to interview only one company. On the other hand, the case company of Thailand has around 700 branches of recyclable garbage stores. This has formed a potential selection and comparison bias.

2. In some parts of the interviews, the respondent cannot share some of the information to the researcher. Therefore, in some part of the information, we could only find the data but could not make comparisons.

3. With regards to the differences between the respondents, we interviewed the owner of the recycling store in Thailand but for Taiwan, we only got to interview the managing department of a franchise. The franchise department management might have a different point of view from an owner, though they were knowledgeable also. 
Acknowledgments: This research work was partially supported by the "Study of identification and early warning of food safety risks of production and supply processes," a key project of the National Natural Science Foundations of China (Project No. 71633002).

Author Contributions: X.C. was the major writer for the first manuscript; C.-T.T. and K.S. were data collectors and analyzers; L.W. led the project and finished theoretical and practical design of the study; F.-S.T. writes for the Introduction and Conclusion sections and was in charge of completing re-vision and re-submission.

Conflicts of Interest: The authors declare no conflict of interest.

\section{Appendix A}

\begin{tabular}{|c|c|c|c|c|c|c|c|c|}
\hline \multirow{3}{*}{ Period } & \multicolumn{7}{|c|}{ Amount of Waste Generated (Tonnes) } & \multirow{3}{*}{$\begin{array}{c}\text { Amount of } \\
\text { Waste } \\
\text { Generated } \\
\text { Per Capita } \\
\text { Per Day (Kg) }\end{array}$} \\
\hline & \multirow[b]{2}{*}{ Total } & \multicolumn{3}{|c|}{ Recycling and Reuse } & \multirow[b]{2}{*}{ Incineration } & \multirow[b]{2}{*}{$\begin{array}{l}\text { Sanitary } \\
\text { Landfill }\end{array}$} & \multirow[b]{2}{*}{ Others } & \\
\hline & & $\begin{array}{c}\text { Bulk } \\
\text { Waste }\end{array}$ & $\begin{array}{l}\text { Recyclable } \\
\text { Waste }\end{array}$ & $\begin{array}{c}\text { Food } \\
\text { Waste }\end{array}$ & & & & \\
\hline 2002 & $7,984,837$ & $\ldots$ & $1,241,837$ & $\ldots$ & $4,316,169$ & $2,130,190$ & 296,642 & 0.982 \\
\hline 2003 & $7,708,019$ & ... & $1,379,158$ & 168,601 & $4,306,049$ & $1,712,889$ & 141,322 & 0.941 \\
\hline 2004 & $7,714,959$ & $\ldots$ & $1,552,804$ & 299,265 & $4,307,737$ & $1,474,166$ & 80,987 & 0.932 \\
\hline 2005 & $7,828,685$ & 29,575 & $1,809,656$ & 464,201 & $4,300,399$ & $1,184,599$ & 40,255 & 0.945 \\
\hline 2006 & $7,791,606$ & 28,646 & $2,160,112$ & 570,176 & $4,163,968$ & 851,015 & 17,688 & 0.936 \\
\hline 2007 & $7,949,448$ & 31,230 & $2,382,191$ & 662,791 & $4,335,770$ & 504,944 & 32,523 & 0.951 \\
\hline 2008 & $7,537,374$ & 44,466 & $2,427,561$ & 691,194 & $4,137,284$ & 236,123 & 747 & 0.896 \\
\hline 2009 & $7,746,019$ & 65,473 & $2,735,591$ & 721,472 & $4,036,404$ & 185,765 & 1,315 & 0.920 \\
\hline 2010 & $7,957,601$ & 80,217 & $3,035,617$ & 769,164 & $3,888,641$ & 181,771 & 2,191 & 0.942 \\
\hline 2011 & $7,554,589$ & 80,326 & $3,052,215$ & 811,199 & $3,468,620$ & 142,155 & 74 & 0.892 \\
\hline 2012 & $7,403,948$ & 88,983 & $3,101,035$ & 834,541 & $3,277,252$ & 102,052 & 85 & 0.869 \\
\hline 2013 & $7,332,694$ & 83,924 & 3,153,406 & 795,213 & $3,208,721$ & 91,355 & 75 & 0.861 \\
\hline 2014 & $7,369,439$ & 65,837 & $3,310,560$ & 720,373 & $3,189,457$ & 83,136 & 76 & 0.863 \\
\hline 2015 & $7,229,290$ & 63,578 & $3,319,617$ & 609,706 & $3,143,054$ & 91,655 & 1,679 & 0.844 \\
\hline 2016 & $7,461,342$ & 60,918 & $3,690,910$ & 575,932 & $2,993,435$ & 77,940 & 62,206 & 0.867 \\
\hline
\end{tabular}

Figure A1. Amount of Waste Generated Statistics in Taiwan. (Source: Environmental Protection Administration Executive Yuan, Taiwan, 2017).

Table A1. Overall Results of the Recycling Industry in Thailand and Taiwan in 2016.

\begin{tabular}{|c|c|c|c|c|c|c|c|}
\hline Items & Content/Type of Products & Iron/Steel & Paper & Glass & Plastic & Metal & Electronic \\
\hline \multirow{3}{*}{$\begin{array}{c}\text { Thailand } \\
\text { (Total volume about } \\
15,817,000 \text { tons) }\end{array}$} & Average Price (NTD) & 4.4 & 3.45 & 4.02 & 4.04 & 43.7 & 15.27 \\
\hline & $\begin{array}{c}\text { Recyclables of } \\
\text { municipal solid waste }\end{array}$ & $5 \%$ & $8 \%$ & $3 \%$ & $17 \%$ & $2 \%$ & $1 \%$ \\
\hline & Volume & $\begin{array}{l}791,000 \\
\text { tons }\end{array}$ & $\begin{array}{c}1,265,000 \\
\text { tons }\end{array}$ & $\begin{array}{c}475,000 \\
\text { tons }\end{array}$ & $\begin{array}{l}2,689,000 \\
\text { tons }\end{array}$ & $\begin{array}{c}316,000 \\
\text { tons }\end{array}$ & $\begin{array}{c}158,000 \\
\text { tons }\end{array}$ \\
\hline \multirow{2}{*}{$\begin{array}{c}\text { Taiwan } \\
\text { (Total volume about } \\
4,253,000 \text { tons) }\end{array}$} & Average Price (NTD) & 4 & 3.1 & 1.15 & 2.8 & 30.5 & 12.1 \\
\hline & Volume & $\begin{array}{c}206,000 \\
\text { tons }\end{array}$ & $\begin{array}{c}2,000,000 \\
\text { tons }\end{array}$ & $\begin{array}{c}420,000 \\
\text { tons }\end{array}$ & $\begin{array}{c}318,000 \\
\text { tons }\end{array}$ & $\begin{array}{c}560,000 \\
\text { tons }\end{array}$ & $\begin{array}{c}75,000 \\
\text { tons }\end{array}$ \\
\hline
\end{tabular}

(Source: Environmental Protection Administration Executive Yuan, Taiwan, 2017; Pollution Control Department, Thailand, 2017.) 
Table A2. Factors in the Recycling Industry between Taiwan and Thailand.

\begin{tabular}{|c|c|c|}
\hline Factors & Thailand & Taiwan \\
\hline Population & $70,000,000$ people & 23,500,000 people \\
\hline Laws/Regulations & Weak & Strong \\
\hline The Cooperation of the Government & $20 \%$ Government & $60 \%$ Government \\
\hline The Cooperation of the Government & $80 \%$ Private & $40 \%$ Private \\
\hline Competition & High Competition & Low Competition \\
\hline Business Order & Thailand and Oversea (China) & Taiwan and Oversea (China) \\
\hline The Intention of the People Who Collect Recyclable Wastes & Most of the people wants to earn money & Most of the people wants to protect the environment \\
\hline How Frequent the Garbage Trucks Collect the Garbage & Twice a Week & Monday-Saturday (General Waste Truck) \\
\hline Effect of the Economic Change & $\begin{array}{l}\text { (General Waste Truck) } \\
\text { Thailand Flood in } 2011\end{array}$ & $\begin{array}{l}\text { Twice a Week (Recyclable Waste Truck) } \\
\text { World Financial Crisis in } 2007\end{array}$ \\
\hline The Variety of Garbage Trucks & General Waste's Truck & General Waste's Truck and Recyclable Waste's Truck \\
\hline The Method of Solid Waste Disposal & $\begin{array}{l}\text { Incineration is the primary method; } \\
\text { disposal in landfills is an auxiliary method. }\end{array}$ & $\begin{array}{l}\text { Landfills and composting is the primary method. } \\
\text { Incineration is the auxiliary method. }\end{array}$ \\
\hline The Classification of the Wastes Disposal & $\begin{array}{l}\text { (1) General waste/(2) Recyclable waste/(3) Hazardous waste/ } \\
\text { (4) Infectious waste }\end{array}$ & (1) Bulky waste/(2) Recyclable waste/(3) Kitchen waste/(4) General waste \\
\hline Age of the Owner & 25 above & 35 above \\
\hline Office Hours & Open Daily & Monday-Saturday \\
\hline & 08:00-18:00 & 08:30-18:30 \\
\hline Location & $\begin{array}{l}\text { Out of the city } \\
1200 \text { square meter }\end{array}$ & $\begin{array}{l}\text { In the City } \\
150-200 \text { square meter }\end{array}$ \\
\hline Manage the Recyclable Wastes & Separate for type of item, Clean and Cut & Separate for type of items \\
\hline Employees in the Headquarter & 60 workers; 1 Owner; 6 Officers; 4 Drivers; 49 Separate Waste Workers & 60 workers; 1 Owner; 13 Officers; 10 Drivers; 36 Separate Waste Workers \\
\hline Price of Materials & Steel $/$ Iron $=4.4 /$ Paper $=3.45 /$ Glass $=4.02 /$ Plastic $=4.04 /$ Metal $=43.7$ & Steel $/$ Iron $=4.5 /$ Paper $=3.1 /$ Glass $=1 /$ Plastic $=2 /$ Metal $=30 /$ \\
\hline (Currency: TWD) & Electronic $=15.2$ & Electronic $=10$ \\
\hline Total Volumes/Year & $1,385,000$ tons & 650,000 tons \\
\hline Types of Volumes/Year & 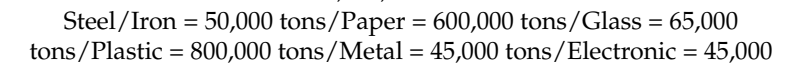 & $\begin{array}{c}\text { Steel } / \text { Iron }=110,000 \text { tons } / \text { Paper }=210,000 \text { tons } / \text { Glass }=20,000 \text { tons } / \\
\text { Metal }=80,000 \text { tons } / \text { Electronic }=67,000\end{array}$ \\
\hline Market Share of Private Sectors & $10 \%$ & $16 \%$ \\
\hline Franchise Fee & NTD 200,000 & NTD 300,000 \\
\hline The Margin & Not Have & NTD 500,000 (pay for every 5 years) \\
\hline Construction Plan and Start-up Costs & NTD 1,500,000 & NTD 250,000-300,000 \\
\hline Revolving Fund & NTD $2,000,000$ & NTD $1,500,000$ \\
\hline Type of Materials & All types of the recyclable wastes (Except: old clothes, and woods) & All types of the recyclable wastes (Except: glass) \\
\hline The Difference in Transportation and Transaction Process & Individual & Depends on Head Office \\
\hline
\end{tabular}




\section{References}

1. Kreith, F. Handbook of Solid Waste Management; McGrawHill: New York, NY, USA, 2002.

2. Kelly, C. Wastewater treatment offers a view into environmental chemicals' risks. In Environmental Facto; National Institute of Environmental Health Science: Durham, NC, USA, 2014.

3. Ackerman, F. Why Do We Recycle? Markets, Values and Public Policy; Island Press: Washington, DC, USA, 2013; pp. 11-18. ISBN 9781597267885.

4. Stewart, B. Household Waste in Social Perspective: Values, Attitudes, Situation and Behavior; Ashgate Studies in Environmental Policy and Practice; Aldershot; Ashgate: Burlington, VT, USA, 2002.

5. Rewlutthum, K. Evaluation of Plastic Waste Management in Thailand Using Material Flow Analysis. Master's Thesis, Science in Environmental Engineering and Management, Bangkok, Thailand, 2013.

6. Kojima, M. International Trade of Recyclable Resource in Asia; IDE Spot Survey No. 29; Institute of Development Economics (IDE): Chiba, Japan; JETRO: Tokyo, Japan, 2005.

7. Eggers, W.D.; Macmillan, P. The Solution Revolution: How Business, Government, and Social Enterprises Are Teaming Up to Solve Society's Toughest Problems; Harvard Business Review Press: Brighton, MA, USA, 2013; ISBN 9781422192191.

8. Phills, J.A., Jr.; Deiglmeier, K.; Miller, D.T. Rediscovering Social Innovation. Stanford Social Innovation Review. Fall 2008, 6, 34-43.

9. Cruz, S.; Gallouj, F.; Paulino, S. Innovation in Local Public Services -the Solid Waste Sector from the perspective of Clean Development Mechanism landfill projects. In Proceedings of the 23rd International Conference of RESER, Aix en Provence, France, 19-21 September 2013.

10. El-Haggar, S.M. Sustainable Industrial Design and Waste Management: Cradle-to Cradle for Sustainable Development; Elsevier: San Diego, CA, USA, 2007; ISBN 9780080550145.

11. Mostert, E. Who should do what in environmental management? Twelve principles for allocating responsibilities. Environ. Sci. Policy 2015, 45, 123-131. [CrossRef]

12. Okumura, S.; Tasaki, T.; Moriguchi, Y. Economic growth and trends of municipal waste treatment options in Asian countries. J. Mater. Cycles Waste Manag. 2014, 16, 335-346. [CrossRef]

13. Iwase, S.D.D. The management of capital allocation for sustainable municipal solid waste management system: A case study of Bang Saen, Thailand. Environ. Asia 2013, 6, 51-59.

14. Daranee, T. Urbanization and Social Change in Developing Countries; Chulalongkorn University Press: Bangkok, Thailand, 2008.

15. Sukholthaman, P. Bangkok Recycling Program: An Empirical Study of an Incentive-Based Recycling Program. Master's Thesis, University of Pennsylvania Scholarly Commons, Bangkok, Thailand, 2012.

16. Chen, K. Taiwan: The World's Geniuses of Garbage Disposal. Available online: https://www.wsj.com/ articles/taiwan-the-worlds-geniuses-of-garbage-disposal-1463519134 (accessed on 24 March 2018). 